\title{
The Role of Financial Globalization through FDI in Driving Inequality in the Sub-Saharan Region
}

\author{
Kossi AYENAGBO ${ }^{1}$ \\ ${ }^{1}$ Lecturer in Economics, Faculty of Economics and Management, University of Kara, Togo \\ Correspondence: Kossi AYENAGBO, Lecturer in Economics, Faculty of Economics and Management, University of \\ Kara, Togo.
}

Received: May 19, 2021

Accepted: July 5, $2021 \quad$ Available online: September 3, 2021

doi:10.11114/aef.v8i5.5342

URL: https://doi.org/10.11114/aef.v8i5.5342

\begin{abstract}
This paper examines the relationship between globalization and income inequality in Sub-Saharan Africa (SSA). Globalization is here measured using trade variables like the openness rate (TO), financial variables including FDI while income inequality is measured by the GINI coefficient. This was achieved by using data from 26 countries over the period 2005-2014, using the System Generalized Method of Moments (SGMM) estimator to obtain results from the African context. The results suggested that trade openness exerted an equalizing effect while financial globalization through FDI has been the critical factor driving inequality in the SSA since 2005. The results also showed that outside of FDI, corruption contributes greatly to widening inequality by about $3 \%$. The effect of the other control variables was all together insignificant. The prevailing economic status as portrayed following on the back of the 2008 financial crisis has led to an increase in inequalities in SSA countries. These results are robust to the using of the KOF Globalization index. Through this research, governments and policymakers have to introduce robust and appropriate policies and interventions in their drive for economic growth to decisively deal with corruption and so direct FDI to economically sound targeted priority programs.
\end{abstract}

Keywords: globalization, FDI, openness rate, income inequality, SGMM , SSA

\section{Introduction}

A series of different processes allowing the interdependence or the interpenetration and the bringing together of economies allows to characterize globalization which is a multidimensional phenomenon. In particular and notably, trade liberalization, financial openness and capital movements, information and communication technologies, international immigration. Globalization has thus brought about a new era in world trade where goods and services move more freely than before and where some developing countries have therefore taken advantage of this phenomenon to become powerful exporting countries (Elmawazini et al, 2013)

Globalization and its effects on economic growth, poverty, inequality, regional differences, and economic integration have increased with the acceleration of the opening of countries to the rest of the world in the era of the global economy. Countries have shown different development patterns and results because they have a great heterogeneity in the degree of globalization. The development gap in SSA countries is a source of inequality and poverty. As such, the linkage between inequality and globalization has been a focus of attention in several studies (Dollar, 2005; Goldberg and Pavcnik, 2007).

External liberalization movements and a broader shift to more market- and export-oriented strategies for development are the underpinnings of rapid globalization in developing countries. The simultaneous emphasis on globalization and the unsatisfactory performance of developing countries in reducing inequalities and poverty levels has given rise to intense debate (Kayizzi-Mugerwa, 2001). There is much work that argues that globalization promotes economic growth and poverty reduction (Koffi et al, 2018). Nevertheless, many have criticized that the economic performance of globalization is disappointing. Moreover, the effects of globalization on growth are not obvious and that this phenomenon benefits more the rich countries with sufficient means to fully enter this globalized economy.

The effect of globalization on income inequality has attracted the attention of many researchers such as Milanovic (2005). According to him, there is growing concern that globalization is worsening income distribution and hampering poverty reduction. In view of these discussions, it is crucial to develop a deeper and more comprehensive analysis of the repercussions of globalization on income inequality and poverty. 
Income inequality is attracting the attention of many researchers and is a policy concern in countries around the world. Particularly in SSA, the increase in income inequality over time is a major concern of policymakers. Despite liberal market-oriented reforms and the integration of countries and technological advances, the benefits of increased income and output growth have not been distributed equally among all segments of the population.

According to Alderson et al (2016), income inequality can increase partly because of changes affecting the labor supply and on the other hand, changes affecting the demand for labor. Both general factors are actively at play in the economies of SSA and as such contributing to the widening income disparities. Fundamentally, designing policy measures that can achieve a more egalitarian society is to understand the causes of inequality.

This study, therefore, undertook an empirical analysis of the relationship between income inequality and globalization using various measures such as trade and financial variables in SSA. We utilized an estimate econometric model, using panel data techniques appropriate for countries south of the Sahara over the period 2005 to 2014. Specifically, using the system GMM estimator is to correct the endogeneity problems that may have appeared in the model. This estimator is best suited for this study because it efficiently handles large size of data series for short periods.

Analysis of data from the estimates shows general increase in FDI flow. Alongside this, is an upswing in corruption levels. The combined effect has led to increase in the level of income inequality in SSA. We also noted increase in the openness rate which is credited with a reduction income inequality in the SSA.

\section{Literature Review}

According to World Development Indicator in 2019 and between 1991 and 2011, trends in inequality were clearly visible in the countries of the region. Nevertheless, seventeen (17) countries, mainly agricultural based economies in West Africa and a few countries in other regions, experienced a decrease in inequalities, while 12 countries, mainly in Southern and Central Africa with economies characterized by significant oil and mining sectors, saw an increase in inequalities.

According to Jerrim and Macmillan (2015) and (Shi, et al, 2013), a better distribution of human capital to build a more just society by decision-makers; an increase in direct taxation and a more efficient tax administration as well as an increase in well-targeted social spending to reduce inequalities; an increase in productivity in the agricultural sector (important factor in the reallocation of labor to other sectors of the economy) which contribute to the reduction of rural poverty; and the process of structural transformation are the determinants of the equalization of inequalities. A country's current production capacity, as embodied in its export structure, affects the extent to which it can shift its production to more manufacturing activity. (Page, 2012).

In general, income disparities are at the root of the unequal distribution of socio-economic and physical facilities between rural and urban areas (Hove, et al, 2013).

One of the main factors of inequality in Africa is the unequal distribution of national resources (Harris and Vermaak, 2015). Research found that, quality education and increased productivity are powerful tools for reducing poverty, but if not accompanied by progressive taxation and well-targeted social protection could accelerate income disparities. The key of transforming current trends of diverging inequalities into converging trends of reducing inequalities in the region is to promote complementary policies that help tackle poverty and income inequality. Supporting the demographic transition with strong social protection; adopting macroeconomic policies that reverse nascent deindustrialization and increase the productivity of the informal sector are very important to address income disparities.

\subsection{Substantial Income Variations}

McKay and Thorbecke (2015) showed that SSA has recorded remarkable economic performance over the past fifteen years. This encouraging trend, which has reversed the stagnation or decline of the previous 25 years, has been accompanied by a noticeable, modest but uneven decrease in overall poverty, as well as substantial income variations across countries. This development is reflected in the variation in the levels and trends of inequality among countries in the African zone. To better understand the problem of poverty reduction in SSA, it is very important to study the levels and trends of inequality in this subregion.

Indeed, as with the typical "rural-urban income gap" debate, the issue of income inequality in Sub-Saharan Africa has not received the attention of many researchers (Anyanwu et al., 2016). It is worth noting that, Africa, at this time in the 1980s, attracted more FDI than Asia, Latin America, and the Caribbean. Macroeconomics. More recently, with the adoption of the Millennium Development Goals (MDGs) in 2000, the focus shifted to poverty reduction and the achievement of the predominantly social MDGs. In addition, in September 2015, the reduction of poverty and inequality became the main objective of the 2030 Agenda for Sustainable Development in SDGs. In this case, (Blomstrom et al., 1994) have shown through their research that foreign capital inflows directly impact economic growth. However, there is an income limit beyond which FDI could have a direct effect on a country's economic growth or development. 


\subsection{Globalization and Income Inequality}

Simon Kuznets (2019) argued that an initial increase in income is associated with an increase in income inequality, while with further increases in income inequality peaks and then begins to decline. The effects of globalization on income inequality have become an important and nagging issue for several researchers. After the 1980s, income inequality and relative poverty increased in most countries. From the 1980s onwards, concerns about the negative effects of global trade and capital movements on income distribution emerged, when the wage gap rapidly increased with the rise of the skill premium. Many developed countries including the United States experienced an increase in Gini coefficients thereafter. It seems to be consistent with the Hecksher-Ohlin's theory according to which international trade reduces the share of workers in advanced countries where capital goods are relatively abundant (Dollar and Kraay, 2004).

Called defensive technological innovation, the effects of globalization on inequality could be significant as technological progress could be affected by international competition and globalization (Akcigit, et al, 2018). Globalization could further worsen income inequality as the production process is divided and part is transferred to foreign countries through outsourcing. The effects of financial globalization on inequality in developed countries are also likely to be negative, as these countries typically export capital and financialization is negatively associated with income distribution.

Several theoretical explanations have been presented on growing income inequality in developing countries as well as on globalization (Goldberg and Pavcnik, 2007). First, developing countries faced fierce international competition with other countries after the 1980s, when almost all countries began to participate in the phenomenon of globalization. Others focused on differences in initial endowments related to outsourcing and international trade in intermediate goods and services. Relatively skilled and richer workers in developing countries produced goods that were previously produced by low-skilled workers in the developed countries. Second, international trade growth and outsourcing worsened the situation of low-skilled workers in developed Nations, while it reversed highly skilled workers in undergoing developing countries, leading to increased income inequalities (Elmawazini et al., 2013).

An increase in FDI and imports of capital goods into developing countries produces the same result, as the latter are linked to production that requires relatively skilled workers. Financial globalization and international capital movements could also have negatives consequences on income distribution in developing countries (Prasad, et al, 2005). Recent studies show that the rate at which FDI can boost the economy's growth, depends mainly on the host economy's social and economic environment (Adegboye et al., 2020; Matthew et al., 2020; Osabohien et al., 2020). Financial openness in developing countries has often resulted in financial instability due to the volatility of capital flows in short-run. Income inequality and poverty have generally worsened following financial crises.

FDI can be linked to increasing inequalities through the reduction of profits, the repression of workers and the dualization of industries. The efforts of developing countries to attract FDI can cause conditions for workers to deteriorate. The deregulation of the labor market with the neoliberal reform has increased the number of unemployed and the proportion of irregular workers, which has led to an increase in wage inequalities (Ignacio-Leiva, 2006). These analyses showed that globalization could increase income inequalities in developing countries. But the effects of globalization on income distribution could be conditional. The negative effects can vary depending on many conditions and absorptive capacity.

Many studies have assessed the effect of globalization on income inequality using different methods of analysis (Bussmann, et al, 2005; Mahler, 2004; Bergh and Nilsson, 2010; Vogli, et al 2014). The Gini coefficient or wage inequality is used as an indicator of income inequality as globalization is captured by variables such as the openness rate, foreign direct investment, tariffs. The relationship between globalization and income distribution is more complex and often conditional in most of these studies. In Colombia, according to Goldberg and Pavcnik (2005), wage inequality and poverty have increased in sectors where the tariff has become relatively lower and the demand for skilled workers has increased. Thus, numerous studies of developing countries have shown that the progress of globalization and the increase in income inequalities have occurred simultaneously (Forster, et al, 2011).

\section{Methodology}

\subsection{Data Sources}

The data in this work is sourced mainly from the World Bank database (WDI). A sample of 26 countries $^{1}$ in SSA were identified for annual observations covering the period 2005 to 2014.

\footnotetext{
${ }^{1}$ South Africa, Benin, Botswana, Burkina Faso, Burundi, Cameroon, Cape Vert, Congo Republic, Ivory Cost C, Gambia, Ghana, Guinea, Mauritius, Kenya, Madagascar, Mali, Mozambic, Namibia, Niger, Uganda, Rwanda, Senegal, Soudan, Tanzania, Togo, Zambia.
} 


\subsection{Model Specification}

The existing literature on globalization and income inequality discussed above led us to the general empirical formulation as follows:

$$
G I N I=f(F D I, T O, X)
$$

Where GINI represents the income inequality, FDI represents the stock of foreign investment, TO represents the degree of openness and $\mathrm{X}$ is a vector for socio-economic variables.

However, the methodological approach follows a panel data model for African countries covering the period 2009 to 2018. Equation (1) is specified as follows:

$$
\operatorname{GINI}_{i t}=\alpha_{i}+\alpha_{1} F D I_{i t}+\alpha_{2} T O_{i t}+\alpha_{3} X_{i t}+\varepsilon_{i t}
$$

Where GINI ${ }_{\text {it }}$ is the country specific effect. i and t respectively, represent the number of individuals (country) and the period (year). GINI represents the measure of inequality; FDI is foreign direct investment (as a percentage of GDP); TO is the openness rate (as a percentage of GDP) and $\mathbf{X}$ is a vector for control variables comprising : GDP is gross domestic product per capita in US dollars; TRADE represents trade in goods as a percentage of GDP; INFLATION measures the general increase in the level of consumer prices; SAVINGS represents gross savings as a percentage of GDP; RESSPr represents private sector financing as a percentage of GDP; URB is the level of urbanization measured by the urban population as a percentage of the total population, and CORR represents the corruption check to capture perceptions of the extent to which public power is exercised for private gain. Descriptive statistics for these variables are presented in Table (1) below. The GINI coefficient (in percentage) varies from 31.5 to 64.8 and shows a high level of income disparity between countries in Sub-Saharan Africa.

Table 1. Descriptive statistics of variables

\begin{tabular}{lccccc}
\hline Variable & Obs. & Average & $\begin{array}{c}\text { Standard } \\
\text { déviation }\end{array}$ & Min & Max \\
\hline Gini & 260 & 44.113 & 7.966 & 31.5 & 64.8 \\
FDI & 260 & 4.522 & 5.064 & -0.840 & 39.456 \\
TO & 260 & 68.566 & 27.640 & 19.459 & 149.780 \\
GDP & 260 & 1855.718 & 2147.437 & 151.682 & 10153.94 \\
RESSPr & 237 & 25.387 & 31.20 & 2.097 & 160.125 \\
SAVINGS & 238 & 17.099 & 9.025 & -7.779 & 46.183 \\
INFLATION & 260 & 7.016 & 6.322 & -2.248 & 36.907 \\
TRADE & 260 & 52.183 & 21.953 & 20.882 & 116.709 \\
URB & 260 & 38.505 & 14.956 & 9.375 & 66.368 \\
CORR & 260 & -0.468 & 0.639 & -1.486 & 1.160 \\
\hline
\end{tabular}

Source: Author based on World Bank Data (WDI)

\subsection{Estimation Technique}

To analyze the effect of globalization on income inequality in SSA, we adopted an econometric approach based on a fixed-effect model for a panel of 26 countries in this region covering the period 2005 to 2014. Further, we took into account the unobserved fixed effects, endogenous independent variables, the presence of heteroskedasticity and autocorrelation across or within the panel by employing the GMM system approach was preferred to that of the GMMs because of the short period required for data analysis (Roodman, 2009).

\section{Results of Estimates and Discussions}

In general, an astute examination of the results shows that in SSA, FDI, the degree of openness (TO) and income per capita (GDP) are the main factors influencing the coefficient of GINI as in the study by Anyanwu et al. (2016). Table 2 below presents the results of the estimates on globalization and income inequality in SSA. The results of the estimates show a significant and positive effect of the coefficient associated with FDI. An increase in FDI of around $1 \%$ leads to an increase in inequalities of around $0.3 \%$.

Unlike FDI, with regard to the variable representing the opening rate, it is negatively associated with the GINI coefficient. An increase in the openness rate of $1 \%$ leads to a decrease in inequality of around $0.3 \%$. Our results are consistent with 
those found by Asteriou et al (2014) covering 27 countries of the European Union. They also found that FDI increases inequality while TO helped to reduce income inequality between countries. Thus, the more open countries in SSA are to foreign commerce, the better the distribution of income is, while on the other hand, the more countries benefit from FDI the more income inequality grows. Along the same lines, the results also show the contribution of trade or trade in goods to reduce inequality by around $0.4 \%$. These results confirm those obtained by other empirical studies (Dollar and Kraay,2004; Silva and Leichenko, 2004)

Regarding income per capita, unlike Ametoglo et al., (2018) who did not find a significant effect of income on the income coefficient, examination of data in this study shows a significant and positive association of income to the increase in inequality of about $4 \%$ in columns (1) and (2). Poor redistribution of the fruits of economic growth would lead to a further increase in income inequality to the detriment of vulnerable populations. (Berg and Ostry,2017). Similarly, the results also showed that private investment increases the level of inequality by about $0.1 \%$. The low level of public investment in Sub-Saharan African countries leads to exploitation of the labor force and poor redistribution of profits from the private sectors (Hernández-Catá, 2000). Companies that always aim to maximize profit are not moving in the direction of a fair distribution of resources. The results in column (3) showed that the coefficients associated with the variables of savings and urbanization are significant and positive. These two variables contributed to the increase in inequality by about $0.2 \%$. High urbanization increases the disparity between urban and rural areas. The increase in inequality due to high urbanization can therefore be explained by the fact that in SSA, populations in urban areas are better off than populations living in rural areas (Kundu, 2003; Smit, 2018). The results in column (4), showed that the variable measuring the level of corruption is positively disposed and significantly correlated with the GINI coefficient. However, an increase in corruption of around $1 \%$ contributed to an increase in income inequality of around $3.2 \%$. Thus, economies with strong controls on corruption with effective governments, of which there are very few in SSA, can provide good or favorable conditions for reducing inequality. However, for much of the literature, corruption worsens income inequality (Cartier-Bresson, 2000; Yusuf et al., 2014).

In summary, the results of this study with regard to the relationship between globalization and income inequality, suggest that trade openness is equalized everywhere and contributes to the reduction of inequalities, but that FDI is detrimental to the reduction of income inequalities in the SSA sub region. Financial globalization through FDI, the poor distribution of per capita income and corruption are the critical driving forces behind the increase in inequality in SSA over the period 2005 to 2014. However, the influences exerted by these variables should not be considered uniform within a given group, nor between groups of countries. In terms of contribution to changes in distribution, the openness rate unlike FDI found by Asteriou et al. (2014) seems to be the main contributing factor over the entire period in the reduction in income inequalities.

Table 2. Results of GMM Arellano and Bond Estimator Estimates

\begin{tabular}{|c|c|c|c|c|}
\hline \multicolumn{5}{|c|}{ Dependent variable : Gini } \\
\hline Variables & $(1)$ & (2) & (4) & \\
\hline \multirow[t]{2}{*}{ FDI } & $0.338 * *$ & $0.318 * *$ & $0.302 * *$ & $0.323 * *$ \\
\hline & $(0.143)$ & $(0.125)$ & $(0.111)$ & $(0.139)$ \\
\hline \multirow[t]{2}{*}{ TO } & $-0.292 * *$ & $-0.259 * * *$ & $-0.258 * * *$ & $-0.301 * * *$ \\
\hline & $(0.107)$ & $(0.0922)$ & $(0.0642)$ & $(0.106)$ \\
\hline \multirow[t]{2}{*}{ GDP } & $4.429 * *$ & $4.429 * *$ & -2.239 & 3.242 \\
\hline & $(1.948)$ & $(1.948)$ & $(1.920)$ & $(2.077)$ \\
\hline \multirow[t]{2}{*}{ COMMERCE } & $0.367 * * *$ & $0.352 * * *$ & $0.325 * * *$ & $0.389 * * *$ \\
\hline & $(0.0909)$ & $(0.0841)$ & $(0.0617)$ & $(0.0942)$ \\
\hline \multirow[t]{2}{*}{ INFLATION } & -0.117 & -0.0660 & -0.00372 & -0.0711 \\
\hline & $(0.178)$ & $(0.144)$ & $(0.130)$ & $(0.147)$ \\
\hline \multirow[t]{2}{*}{ SAVINGS } & 0.0974 & $0.180 *$ & $0.202 * *$ & 0.0423 \\
\hline & $(0.0912)$ & $(0.0941)$ & $(0.0820)$ & $(0.110)$ \\
\hline \multirow[t]{2}{*}{ RESSPr } & & $0.113 * * *$ & $0.135 * * *$ & \\
\hline & & $(0.0359)$ & $(0.0270)$ & \\
\hline \multirow[t]{2}{*}{ URB } & & & $0.230^{* *}$ & \\
\hline & & & $(0.0857)$ & \\
\hline \multirow[t]{2}{*}{ CORRUPTION } & & & & $3.184^{*}$ \\
\hline & & & & (1.714) \\
\hline \multirow[t]{2}{*}{ Constant } & 11.06 & $30.33 * * *$ & $42.35 * * *$ & $21.16^{*}$ \\
\hline & $(10.41)$ & $(9.332)$ & $(9.264)$ & (11.69) \\
\hline Observations & 238 & 220 & 220 & 238 \\
\hline Number of Id & 25 & 24 & 24 & 25 \\
\hline
\end{tabular}

Robust standard errors in parentheses

$* * * \mathrm{p}<0.01, * * \mathrm{p}<0.05, * \mathrm{p}<0.1$

Source : Author, based on Stata Software 
The robustness check was done using the KOF Globalization index and three of its main components, the Economic Globalization, the Trade Globalization and the Financial Globalization. The results are presented in Table 3. Albeit, the overall globalization index reduced inequalities in Sub Saharan Africa, this effect is not statistically significant. The effect of the Economic and Financial Globalization goes in the same direction. However, Trade Globalization tends to increase inequalities.

Table 3. Results of Running a Robustness Check Using the KOF Globalizations Index and three of its Main Components

\begin{tabular}{|c|c|c|c|c|}
\hline \multicolumn{5}{|l|}{ Dependent variable: Gini } \\
\hline & (1) & (2) & (3) & (4) \\
\hline \multirow[t]{2}{*}{ GDP } & 0.0253 & 0.0253 & 0.0252 & 0.0207 \\
\hline & $(0.224)$ & $(0.225)$ & $(0.225)$ & $(0.225)$ \\
\hline \multirow[t]{2}{*}{ INFLATION } & 0.0646 & 0.0556 & 0.0519 & 0.0605 \\
\hline & $(0.123)$ & $(0.124)$ & $(0.123)$ & $(0.124)$ \\
\hline \multirow[t]{2}{*}{ KOF Globalization Index } & -0.127 & & & \\
\hline & $(0.143)$ & & & \\
\hline \multirow[t]{2}{*}{ URB } & -0.0143 & -0.00630 & 0.0180 & -0.0282 \\
\hline & $(0.624)$ & $(0.636)$ & $(0.634)$ & $(0.634)$ \\
\hline \multirow{2}{*}{ CORRUPTION } & 1.237 & 1.047 & 0.978 & 1.093 \\
\hline & $(0.744)$ & $(0.761)$ & $(0.751)$ & $(0.737)$ \\
\hline \multirow[t]{2}{*}{ SAVINGS } & $0.0646 * *$ & $0.0596 * *$ & $0.0594 * *$ & $0.0588 * *$ \\
\hline & $(0.0298)$ & $(0.0294)$ & $(0.0295)$ & $(0.0294)$ \\
\hline \multirow[t]{2}{*}{ RESSPr } & $0.123 * * *$ & $0.107 * * *$ & $0.105 * * *$ & $0.107 * * *$ \\
\hline & $(0.0323)$ & $(0.0268)$ & $(0.0271)$ & $(0.0263)$ \\
\hline \multicolumn{2}{|l|}{ KOF Economic Globalization Index } & $\begin{array}{l}-0.0148 \\
(0.0836)\end{array}$ & & \\
\hline KOF Trade Globalization Index & & & $\begin{array}{l}0.00336 \\
(0.0727)\end{array}$ & \\
\hline KOF Financial Globalization Index & & & & $\begin{array}{l}-0.0292 \\
(0.0720)\end{array}$ \\
\hline Constant & $\begin{array}{l}41.86 * * * \\
(6.951)\end{array}$ & $\begin{array}{l}37.23 * * * \\
(4.841)\end{array}$ & $\begin{array}{l}36.59 * * * \\
(4.449)\end{array}$ & $\begin{array}{l}37.88 * * * \\
(4.782)\end{array}$ \\
\hline
\end{tabular}

\section{Conclusion and Policy Implications}

Globalization is guilty of inequalities. Globalization plays an essential role in the evolution of inequalities. Indeed, it is the source of the gap between capital income and labor income. Generally, it leads to a decrease in the marginal tax rate on income or on corporations. Indeed, it has generally led to a decline in the marginal tax rate on income or on corporations.

Therefore, this paper analyzed the effect of globalization on income inequality in SSA on a sample of 26 countries covering the period from 2005 to 2014. The results showed that policies in favor of increasing the degree of openness would allow a reduction in income inequalities in all the countries of SSA.

Given the low level of per capita income in most of these countries, strong and compelling policies aimed at improving the control of corruption and especially at the reduction of financial globalization, in particular FDI, must be instituted. A combination of these can lead to a significant reduction in income inequalities within the countries of the region. The results also explained that the level of urbanization leads to an increase in inequality due to the limited availability of services in the urban environment. Therefore, enactment and effective implementation of appropriate policies for the improvement of the socio-economic conditions of populations in rural areas should aim at increasing public investments to provide infrastructure for basic needs and amenities that will consequently reduce inequalities. To reduce economic inequality, governments or public authorities can reduce economic inequality through the provision of public services. To this end, they can make certain services accessible to the entire population and create public facilities, thus making it possible to reduce income inequalities and even the standard of living of households.

\section{References}

Adegboye, F. B., Adesina, T. F., Ojeka, S. A., Akinjare, V. A., \& Olokoyo, F. O. (2020). Foreign direct investment, dual gap model and economic development in Sub-Saharan Africa. Cogent Social Sciences, 6(1). https://doi.org/10.1080/23311886.2020.1743138 
Akcigit, U., Ates, S. T., \& Impullitti, G. (2018). Innovation and trade policy in a globalized world. International Finance Discussion Papers 1230. https://doi.org/10.17016/IFDP.2018.1230

Alderson, A. S., Beckfield, J., \& Nielsen, F. (2016). Exactly How Has Income Inequality Changed?: Patterns of Distributional Change in Core Societies. International Journal of Comparative Sociology. https://doi.org/10.1177/0020715205059208

Ametoglo, M., Ping, G., \& Ossadzifo, W. (2018). Regional integration and income inequality in ECOWAS zone. Journal of Economic Integration, 33(3), 604-628. https://doi.org/10.11130/jei.2018.33.3.604

Anyanwu, J. C., Erhijakpor, A. E. O., \& Obi, E. (2016). Empirical Analysis of the Key Drivers of Income Inequality in West Africa. African Development Review, 28, 18-38. https://doi.org/10.1111/1467-8268.12164

Berg, A. G., \& Ostry, J. D. (2017). Inequality and unsustainable growth: Two sides of the same coin? IMF Economic Review, Palgrave Macmillan; International Monetary Fund, 65(4), $792-815$. https://doi.org/10.1057/s41308-017-0030-8

Bergh, A., \& Nilsson, T. (2010). Do liberalization and globalization increase income inequality? Elsevier..26(4), 488-505. https://doi.org/10.1016/j.ejpoleco.2010.03.002

Blomstrom, M., Lipsey, R. E, \& Zejan, M. (1994). What explains the growth of developing countries? In Baumol, W. J., Nelson, R.R., Wolff, E.N. (eds) Convergence of productivity. Oxford University Press, New York, pp. $243-256$.

Bussmann, M., Oneal, J. R., \& De Soysa, I. (2005). The effect of globalization on national income inequality , In: Comparative Sociology. 4(3), pp. 285-312 cited In : "L’impact Des Investissements Directs Etrangers Sur La Réduction De La Pauvreté Dans L'UEMOA” (Kouame Mathieu Vincent, 2019). IOSR Journal of Economics and Finance (IOSR-JEF), 1O(4) Ser. I (Jul. - Aug 2019), 74-85. https://doi.org/10.1163/156913305775010089

Cartier-Bresson, J. (2000). 'Economics of Corruption,' OECD Observer, n. 220, April, 25-27. In Determinants of Economic Corruption in the Arab Countries: Dangers and Remedies (Kamel Touati, 2014). Journal of Economics Studies and Research, 2014(2014).

Dollar, D. (2005). Globalization, Poverty, and Inequality since 1980. The World Bank Research Observer, 20(2), 145-175. https://doi.org/10.1093/wbro/lki008

Dollar, D., \& Kraay, A. (2004). Trade, Growth, and Poverty. The Economic Journal, 114(493), F22-F49. https://doi.org/10.1111/j.0013-0133.2004.00186.X

Elmawazini, K., Sharif, A., Manga, P., \& Drucker, P. (2013). Trade globalization, financial globalization and inequality within south-east Europe and cis countries. The Journal of Developing Areas 47, 303-317. https://doi.org/10.1353/jda.2013.0030

Forster, M., Chen, W., \& Llenanozal, A. (2011). Divided we stand: Why inequality keeps rising. Paris, Organisation for Economic Co-operation and Development (OECD). Retrieved from http://hdl.voced.edu.au/10707/196611

Goldberg, P. K., \& Pavcnik, N. (2007). Distributional Effects of Globalization in Developing Countries. Journal of Economic Literature, 45(1), 39-82. https://doi.org/10.1257/jel.45.1.39

Harris, G., \& Vermaak, C. (2015). Economic inequality as a source of interpersonal violence: Evidence from sub-Saharan Africa and South Africa. South African Journal of Economic and Management Sciences, 18(1), $45-57$. https://doi.org/10.17159/2222-3436/2015/v18n1a4

Hernández-Catá, M. E. (2000). Raising growth and investment in Sub-Saharan Africa: what can be done?. IFM Policy Discussions Paper, PDP/00/4.

Hove, M., Ngwerume, E. T., \& Muchemwa, C. (2013). The urban crisis in Sub-Saharan Africa: A threat to human security and sustainable development. University of Zimababwe Library, UZeScholar Institutional Repository. https://doi.org/10.5334/sta.ap

Ignacio-Leiva, F. (2006). Neoliberal and neostructuralist perspectives on labour flexibility, poverty and inequality: A critical appraisal. New Political Economy, 11(3), 337-359. https://doi.org/10.1080/13563460600840175

Jerrim, J., \& Macmillan, L. (2015). Income inequality, intergenerational mobility, and the great Gatsby curve: is education the key? Social Forces. Social Forces, 94(2), 505-533. https://doi.org/10.1093/sf/sov075

Kayizzi-Mugerwa, S. (2001). Globalisation, Growth and Income Inequality: The African Experience (No. 186). OECD Development Centre Working Papers. OECD Publishing.

Koffi, S. L. Y., Gahé, Z. S. Y., \& Ping, Z. X. (2018). Globalization Effects on Sub-Saharan Africa: The Impact of International Trade on Poverty and Inequality. International Journal of Innovation and Economic Development, 
Inovatus Services Ltd., 4(3), 41-48. https://doi.org/10.18775/ijied.1849-7551-7020.2015.43.2005

Kundu, A. (2003). Urbanisation and Urban Governance: Search for a Perspective beyond Neo-Liberalism. Economic and Political Weekly 38, 3079-3087. Retrieved from https://www.jstor.org/stable/4413810

Kuznets, S. (2019). Book "The Gap between Rich and Poor", chapter "Economic growth and income inequality", 1st Edition, taylorfrancis.com, eBook ISBN9780429311208. https://doi.org/10.4324/9780429311208-4

Mahler, V. A. (2004). Economic globalization, domestic politics, and income inequality in the developed countries: A cross-national study. Comparative Political Studies, 37(9), 1025-1053. https://doi.org/10.1177/0010414004268849

Matthew, O. A, Babajide, A. A., Osabohien, R., Adeniji , A., Ewetan, O. O., Adu, O., ... Itua, O. (2020). Challenges of accountability and development in Nigeria. Journal of Money Laundering Control, 23(2), 387-402. https://doi.org/10.1108/JMLC-10-2019-0086

McKay, A., \& Thorbecke, E. (2015). Economic growth and poverty reduction in sub-Saharan Africa: current and emerging issues. Oxford University Press. https://doi.org/10.1093/acprof:oso/9780198728450.001.0001

Milanovic, B. (2005). Can we discern the effect of globalization on income distribution? Evidence from household surveys. The World Bank Economic Review, 19(1), 21-44. https://doi.org/10.1093/wber/lhi003

Osabohien, R., Awolola, O. D., Matthew, O., Itua, O. Q., \& Elomien, E. (2020). Foreign direct investment inflow and employment in Nigeria. Investment Management and Financial Innovations, 17(1), 77-84. https://doi.org/10.21511/imfi.17(1).2020.07

Page, J. (2012). Can Africa industrialise? Journal of African Economies, 21(suppl_2), ii86-ii124. https://doi.org/10.1093/jae/ejr045

Prasad, E., Rogoff, K., Wei, S. J., \& Kose, M. A. (2005). Effects of financial globalization on developing countries: some empirical evidence. In India's and China's recent experience with reform and growth (pp. 201-228), In: "On the Impact of Globalization on Financial Development: A Multi-country Panel Study", European Journal of Sustainable Development (Mehmet, B., Hasan, G., Godwin, O. W., 2019), https://doi.org/10.14207/ejsd.2019.v8n1p350

Roodman, D. (2009). A Note on the Theme of Too Many Instruments. Oxford Bulletin of Economics and Statistics, 71, 135-158. https://doi.org/10.1111/j.1468-0084.2008.00542.x

Silva, J. A., \& Leichenko, R. M. (2004). Regional Income Inequality and International Trade. Economic Geography, 80, 261-286. https://doi.org/10.1111/j.1944-8287.2004.tb00235.x

Smit, W. (2018). Urban Governance in Africa: An Overview. International Development Policy | Revue internationale de politique de developpement, 10, 55-77. In Urbanisation and Urban Governance in Ghana: Identifying Key Actors and their Roles (Adade, 2020). African Journal of Inter/Multidisciplinary Studies, 2020. https://doi.org/10.4000/poldev.2637

Vogli, R. D., Kouvonen, A., Elovainio, M., \& Marmot, M. (2014). Economic globalization, inequality and body mass index: a cross-national analysis of 127 countries. Critical Public Health, 24(1), 7-21. https://doi.org/10.1080/09581596.2013.768331

Yusuf, M., Malarvizhi, C., Mazumder, M. N. H., \& Su, Z. (2014). Corruption, Poverty, and Economic Growth Relationship in the Nigerian Economy. The Journal of Developing Areas, 48(3), 95-107. https://doi.org/10.1353/jda.2014.0042

\section{Copyrights}

Copyright for this article is retained by the author(s), with first publication rights granted to the journal.

This is an open-access article distributed under the terms and conditions of the Creative Commons Attribution license which permits unrestricted use, distribution, and reproduction in any medium, provided the original work is properly cited. 